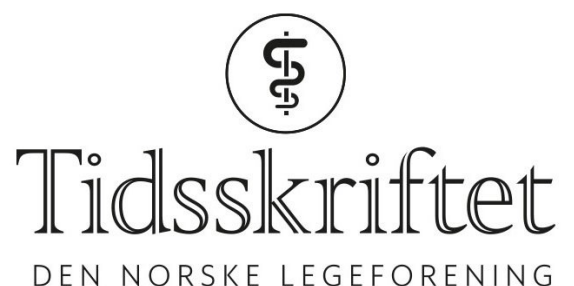

\title{
Fort Borgar
}

INTERVJU

RUNE SKOGHEIM

E-post: runeskogheim@hotmail.com

Han har forsvart Notoddens ære og notoddingenes helse i en mannsalder, men Borgar Flaaten drømmer ikke om å bli slått til ridder. Et kompliment fra barndommen var nok for et helt liv.

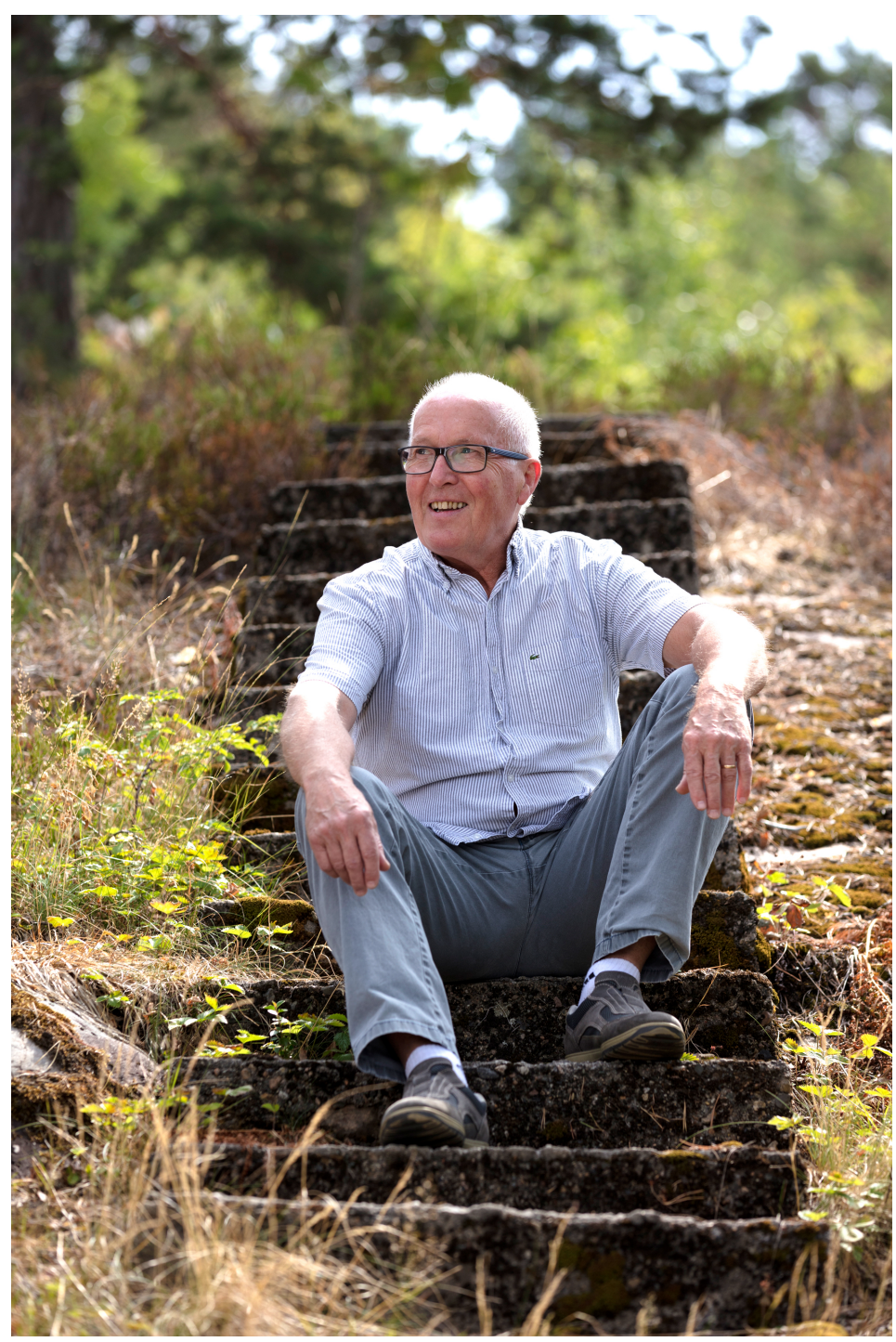

Alle foto: Christian Tunge 
- Jeg husker det som en av de største hedersbetegnelsene jeg har fått. Det var en ettermiddag jeg gikk sammen med to kompiser opp brattbakken og skulle hjemover. På den tiden var det et geografisk klasseskille på Notodden, der «Grønnbyen» var for industriarbeiderne mens industrifunksjonærene bodde på «Villamoen». Familien vår var verken eller. Fatter’n tjente bra som lege, men vi levde nøkternt og det var ikke noe jåleri. Så da den ene industriarbeidersønnen stoppet opp og så på meg og sa: «Du er ikke som de andre du, Borgar, du er en av oss!» ble jeg virkelig glad langt inni meg. Den følelsen sitter igjen.

\section{På fornavn med fellesskapet}

Gastroenterologen sitter i en enkel stol på plattingen foran den lille rødmalte hytta utenfor Drøbak. Listesagen har fått en velfortjent pause og sagflisføyken har lagt seg. Melkeveien 10 er adressen han nyter den stekende sommeren 2018 på, men den er likevel bare en liten planet som kretser rundt sentrum i hans univers. Notodden.

- Du er lidenskapelig lokalpatriot og har vært en sterk stemme for hjemstedet ditt og sykehuset der. Hvordan er det å være legen som så mange i byen vet hvem er?

- Jeg tror ikke folk går rundt og ser på meg som «overlegen», de ser på meg som Borgar, og det er sånn jeg ønsker at de skal se meg. Jeg vil ikke at det skal være noen avstand mellom oss på grunn av hvem jeg er eller hva jeg gjør. I gamle dager var det sykepleiere som kalte meg for «Flaaten», det synes jeg ble altfor høytidelig. Jeg trives best med å være på fornavn, da kommer man nærmere folk, sier han.

\section{Borgar Flaaten}

Sivilstatus: f. 1944, gift med kollega Hanne Thürmer

Cand.med. 1970

Spesialist i fordøyelsessykdommer 2000

1973-77 Assistentlege St. Josephs Hospital

1977-8o Assistentlege Ullevål sykehus

1980-97 Assisterende overlege Notodden sykehus, inkludert 3 md. på Drammen sykehus

1991-95 Kommunestyrerepresentant

1997-2002 Assistentlege, senere overlege Regionsykehuset i Trondheim

2002-07 Avdelingssjef medisinsk avdeling, Blefjell sykehus Notodden, deretter overlege

frem til pensjon ved 67 år

2015-19 Kommunestyrerepresentant, fylkestingsrepresentant 2011-15

Dette er tydelig viktig for Borgar. Å være på fornavn med fellesskapet. Selv om KrF alltid har vært hans parti, har han personlig stor sans for sosialdemokratiet.

- Etter som årene går, skjønner man at det å eie store hus og flotte båter betyr lite, det viktigste er at man gjør en god jobb. Jeg har stor respekt for det elektrikere, snekkere og rørleggere får til, jeg har prøvd meg nok som hobbysnekker til å vite hvor lett det er å gjøre brølere. Alle jobber er verdifulle. Og blir det for store forskjeller i et samfunn, da blir det ufred.

\section{Flyktet landet etter fysikktabbe}

Huset som Borgar vokste opp i, lå på torget på Notodden. Faren hadde legepraksis i første etasje, mens familien bodde i andre. Den lille gutten ble tidlig nysgjerrig på farens arbeid og hva som foregikk under føttene hans, og ekstra lange ble ørene en dag politiet hadde tatt med en promillekjører for blodprøve og klinisk test.

- Etter hvert hører jeg faren min si «Sju ganger seks, hva er det?», hvorpå det ble dødsens stille der inne. Så gjentar han igjen, litt høyere: «Sju ganger seks?», men det var fortsatt ingen som svarte. Jeg ble mer og mer nervøs og tenkte at nå er fatter'n virkelig ille ute! Til 
slutt ropte jeg ut: «To og førr!». Etterpå fikk jeg jo vite at det var sjåføren som skulle svare, he-he.

Den lille gutten med gangetabellen satte seg et skinnende mål om en dag å bli lege. Men den dagen han skulle ta eksamen artium i fysikk, ble plutselig radius til diameter og drømmen så ut til å briste.

- Jeg glemmer det aldri. Jeg hadde fått følgefeil hele veien og grein som ei bikkje da jeg kom hjem. Jeg bomma i både fysikk og matte, og hvis jeg skulle studere medisin, måtte jeg bare komme meg ut i verden, forklarer Borgar.

Dermed dro han til Bonn, til et autoritært universitetsregime der han fikk full forståelse for studentopprøret som blåste hatten av mang en høyneset professor i 1968, året etter at han dro.

- Etter første avdeling fortsatte jeg i Oslo. Da vi kikket uforstående i mikroskopet der var det mer sånn: «Hei du, kom hit litt a! Hva er det her for no’a? Detta skjønner jeg ikke!». Det hadde vi aldri turt å si i Tyskland, smiler den hjemkomne sønnen, som er full av lovord om sine norske medstudenter.

\section{Klassekampen krever forklaring}

Borgar har et liv fullt av historier som fortelles med en slags tøylet iver for ikke å bli for lange, mens lyden av båter freser forbi på fjorden nedenfor. Vi sitter under et hudløst skjelett av et terrassetelt og må stole på de høyreiste furuene over oss for å begrense antallet thymin-dimere som svis inn i DNA-et vårt. Det er mange somre siden han fikk sin første jobb på St. Josephs hospital i Porsgrunn.

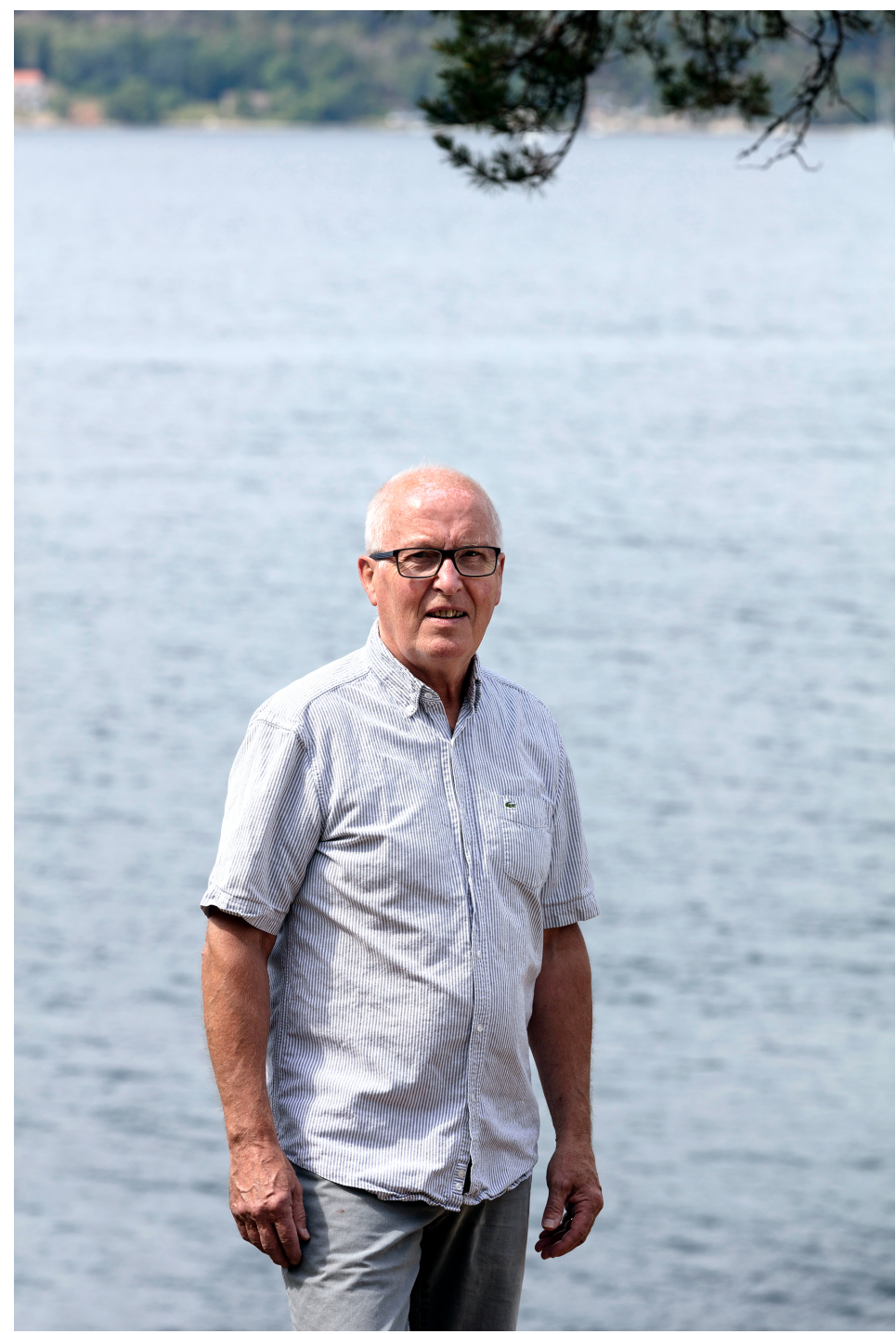


- Der var det nonnene som var sykepleiere, og de behandlet oss meget elegant for å si det sånn. Etter søndagsvisitten ble vi invitert inn i «Palmehaven», hvor vi fikk servert kaffe og likør, før vi satte oss i bilen og kjørte hjem, he-he!

Den unge legen fortsatte sin karriere på Ullevaal, hos professor Erik Enger, ved avdeling for nyremedisin og intoksikasjon. En uke etter at han hadde behandlet et ungt par for heroinoverdose, men måtte skrive dem ut fordi de ikke hadde noe oppfølgingstilbud, kimte telefonen. Paret var blitt funnet døde i leiligheten sin, og nå ringte Jon Michelet fra Klassekampen og ville ha svar.

- Åh, nå får jeg et kjempeproblem! tenkte jeg. Men Michelet var grundig og prøvde ikke å henge ut meg for det som hadde skjedd. Han var en flink og flott type. Men Erik Enger spøkte med at jeg bare kunne glemme å komme inn i USA noen gang etter å ha hatt bildet mitt i Klassekampen på den tiden, forteller Borgar muntert, mens jeg diskret prøver å flytte stolen min etter furuskyggen.

Etter hvert ble det magesekker og tarmhuler som ble hans verden, og han har lagt ut på utallige oppdagelsesreiser med endoskopet for å kartlegge farlig farvann i kroppens mørkeste kanaler.

- Warren \& Marshalls oppdagelse av Helicobacter pylori husker jeg som et høydepunkt. Marshall infiserte jo seg selv med bakterien og fikk gastritt så det suste! Selv hadde jeg pasienter som fortalte meg at de gikk sidegater på vei hjem fra jobb fordi de plutselig måtte kaste opp. Og så kunne vi plutselig kurere dem! Det var utrolig moro å være med på.

\section{Natt over Notodden}

Borgar forlovet seg den første julen han var hjemme fra Bonn på juleferie, men da begge senere var tilbake på Notodden ble hverdagen vanskeligere enn de hadde forestilt seg.

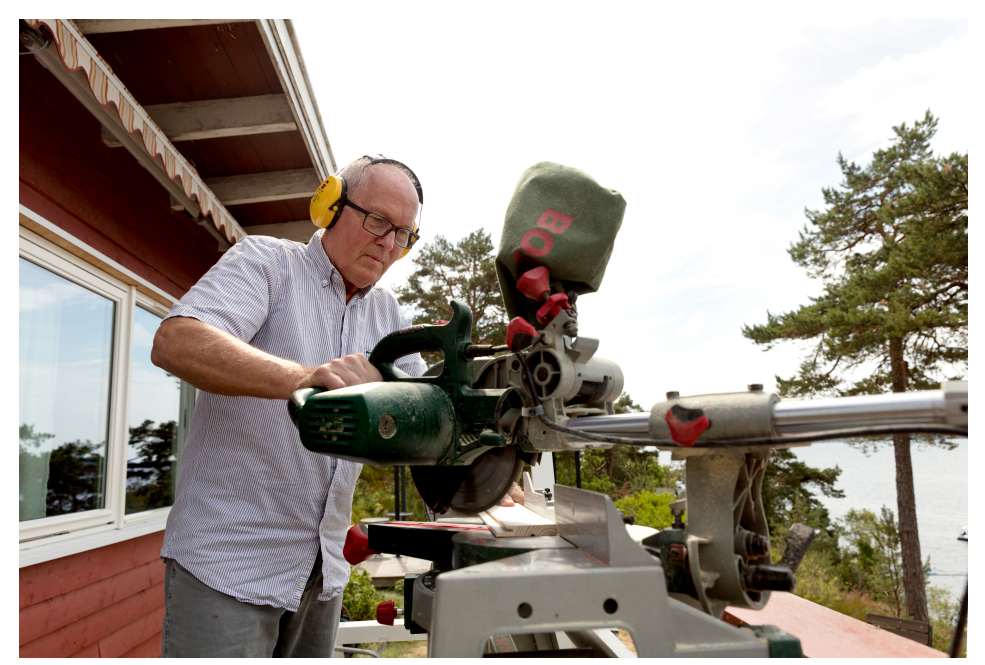

- I starten gikk jeg todelt vakt og jobbet nesten hele tida, i tillegg kjørte jeg ofte legevakter for faren min. På et tidspunkt hadde jeg fri to onsdager i måneden. Jeg led ingen nød, men senere har jeg skjønt at jobben som lege tok for stor plass i ekteskapet, og etter hvert vokste vi fra hverandre. Vi legene var rett og slett egoister, ganske mange av oss...

Tretti års ekteskap endte med brudd. En mørk sky hadde lagt seg over den kjære hjembyen hans, og den fortvilte familiefaren reiste til Trondheim for å søke trøst i enda mer jobb og videre spesialisering.

- Jeg ville bare vekk. Det som skjedde var... det var et nederlag, for å si det rett ut.

- Hvorfor var det et nederlag?

- Jeg vet ikke... det å ikke klare å løse problemene mine, men til slutt innse at ting var blitt for vanskelig og at jeg måtte gi opp. Jeg hadde også brutt et av de ti bud. Det var tøft.

- Tror du leger i dag prioriterer annerledes? 
- Det har helt klart forandret seg til det bedre. Hadde jeg bedt om pappapermisjon i min tid, hadde de jo lagt meg rett inn på Gaustad. Det var helt utenkelig. Nå oppmuntrer jeg alle mine mannlige kolleger til å ta så mye permisjon som mulig, «vær så nær ungene dine som du overhodet kan!», sier jeg. Heldigvis har jeg et godt forhold til både barna og barnebarna mine, men samlivsbrudd, det kan jeg love deg, det er ikke noe å trakte etter. Men for å sitere den gamle forlagsdirektøren Andreas Skartveit: «På ekteskapets vei går du barbeint. Blir det for mye småstein på den veien, så stopper det opp av seg sjøl».

\section{Pelé med Viagra til Norge}

Borgar er i balanse nå. Mindre jobb og mer familie. Flere gulvlister og færre epikriser. Han løp til og med New York City Marathon etter å ha passert 70 år.

- En sunn sjel i et sunt legeme, var slagordet fra ungdomstiden i KFUM. Det har jeg prøvd å leve opp til, selv om jeg ikke alltid har lyktes like godt.

- Hva legger du i å ha «en sunn sjel»?

- Å være hederlig og ærlig. For meg er det også viktig med et nært forhold til en levende religion som ikke er stiv og statisk, men som utvikler seg. Jeg er veldig glad for at kirken har blitt mer åpen og raus. Det sloss jeg faktisk litt for i 1980-årene gjennom å skrive debattinnlegg om anerkjennelsen av homofile mennesker til menighetsbladet. Det ble for sterk kost for distributøren, så menighetsbladet endte til slutt som et innstikk i lokalavisen. Foruten speideren var fotball Borgars store lidenskap som ung, og han glemmer aldri da han ved et lykketreff befant seg i Stockholm under semifinalen i VM mellom Brasil og Frankrike i 1958.

- Jeg så Garrincha drible rundt med det rare beinet sitt, Gylmar som var en panter i mål, og selvfølgelig Pelé, som nettopp hadde fylt 17 år. Det var fotball som jeg aldri før hadde sett det, helt fenomenalt! jubler den tidligere indreløperen på Sportsklubben Snøggs juniorlag. Mange år senere fikk Borgar nyss i at barndomshelten Pelé skulle komme til en legemiddelkongress i Oslo. Viagra hadde kapret seg fotballgeniet for å reise merkevaren til nye høyder.

- Han var veldig opptatt av å understreke at han selv ikke hadde noen problemer på det området, men at han hadde skjønt at det var en del andre mannfolk som trengte hjelp og at han derfor gjerne ville bidra. Da han var ferdig med å snakke, fikk publikum mulighet til å stille ham spørsmål. «Jeg må!», tenkte jeg og lette febrilsk etter de engelske ordene, forteller han.

Slik endte Borgar opp på scenen med Pelé, under Viagras vinger. Svaret på spørsmålet om hvordan brasilianeren klarte å forbli en flott fyr etter all suksessen forsvant i en stjernetåke han svever i den dag i dag.

\section{Fikk elektrosjokk av kona}

I motsetning til gastroskopet er fotballskoene nå lagt på hylla, og selv om sjelen fortsatt vil fremover, har legemet begynt å bremse farten på lokomotivet Borgar.

- Jeg har prøvd å holde meg i god form hele veien, men så fikk jeg atrieflimmer. Kona måtte sjokke meg første gangen, og nå...

- Vent litt. Kona di ga deg elektrosjokk da du fikk flimmer?

- Ja, hun er kardiolog da. Jeg kjente det natten før et fylkesmøte i KrF, så vi dro til sykehuset på morgenkvisten og hun tok EKG av meg for å bekrefte diagnosen. Hjertet fortsatte å humpe, og da jeg holdt et innlegg på møtet var det helt kaos i brystkassa. På kvelden dro vi til sykehuset, så hun fikk sjokka meg. Det gikk fint. Siden har jeg vært på Feiring og fått ablasjon, og jeg må si at helsevesenet har fungert fantastisk bra for meg. Vi er privilegerte her i landet, slår han fornøyd fast. 
Det blir nok med det ene maratonløpet i New York for Borgar, men i den rødmalte stua i Melkeveien 10 er det fortsatt lister som skal kappes, kjøkken som skal fikses og tusen andre gjøremål som skal spores opp og rettes på. Selv om han gjerne skulle fikset hurtigtogbane fra Oslo til Bergen via Notodden også, er det grenser for hva selv en notodding kan få tid til. Men selve historien om Borgar Flaatens fanesak fra tiden i kommunestyret, den kan ingen klokker eller timeglass stoppe.

- Så du har ikke gitt opp ennå?

- Vel... jeg må kanskje innrømme at for mitt vedkommende har nok akkurat det toget gått.

Publisert: 17. september 2018. Tidsskr Nor Legeforen. DOI: 10.4045/tidsskr.18.0634

(C) Tidsskrift for Den norske legeforening 2020. Lastet ned fra tidsskriftet.no 